\title{
Biodiversity, Antimicrobial Potential, and Phylogenetic Placement of an Endophytic Fusarium oxysporum NFX 06 Isolated from Nothapodytes foetida
}

\author{
Sogra Fathima Musavi and Raj Mohan Balakrishnan \\ Department of Chemical Engineering, National Institute of Technology Karnataka, Srinivasa Nagar, Surathkal, \\ Karnataka 575 025, India \\ Correspondence should be addressed to Raj Mohan Balakrishnan; rajmohanbala@gmail.com
}

Received 30 September 2013; Revised 31 October 2013; Accepted 5 November 2013

Academic Editor: Simona Nardoni

Copyright (C) 2013 S. F. Musavi and R. M. Balakrishnan. This is an open access article distributed under the Creative Commons Attribution License, which permits unrestricted use, distribution, and reproduction in any medium, provided the original work is properly cited.

\begin{abstract}
Biodiversity of endophytic fungi associated with the medicinal plant Nothapodytes foetida of Agumbe forest was determined and evaluated for its microbial activity. A total of 170 endophytic isolates were obtained from leaf, stem, seed, and fruit tissues of Nothapodytes foetida. The dominant endophytic fungi belong to genera Fusarium, Penicillium, Aspergillus, and Colletotrichum. Maximum endophytic isolates were obtained from leaves segments followed by fruit, stem, and seed tissues. Hyphomycetes were the dominant group found with $75.29 \%$ over other fungal groups. Shannon-Weiner and Simpson indexes showed rich diversity of endophytic fungi suggesting even and uniform occurrence of various species. $88.57 \%, 74.28 \%, 62.85 \%$, and $65.71 \%$ of isolates have shown activity against Staphylococcus aureus (ATCC 25923), Pseudomonas aeruginosa (ATCC 27853), Escherichia coli (ATCC 25922), and Candida albicans (ATCC 69548), respectively. One of the isolate NFX 06 isolated from leaf has showed considerable antimicrobial activity against all the test pathogens. It was identified as Fusarium oxysporum by ITS sequence analysis; the nucleotide sequence was submitted in the GenBank with an accession number KC914432. Phylogenetic relationship confirmed that the strain F. oxysporum NFX 06 has evolved from an endophytic ancestor.
\end{abstract}

\section{Introduction}

Endophytes are microbes that colonize living, internal tissues of plants without causing any immediate, overt negative effect [1]. Endophytic fungi represent an important and quantifiable component of fungal diversity, with an estimate of at least 1 million species [2-4]. They are found in nearly all plant families including bryophytes [5], pteridophytes [6], gymnosperms [7], and both monocotyledonous [8] and dicotyledonous angiosperms $[9,10]$. Endophytic fungal community has been found in plants living in a unique ecosystem [11], which can be a source for a variety of bioactive metabolites such as antibiotics, antimycotics, immunosuppressants, and anticancer compounds [12].

The discovery of novel antimicrobial metabolites from endophytes is an important alternative to overcome the increasing levels of drug resistance by plant and human pathogens [13-15]. The antimicrobial compounds can be used as drugs and also as food preservatives in the control of food spoilage and foodborne diseases [16]. Thus there is a huge interest across the world to determine the biodiversity of endophytic mycoflora within the host for its novel and undescribed species $[17,18]$. In this study an attempt has been made to isolate the endophytic mycoflora of $N$. foetida, to screen for their antimicrobial activity against selected human pathogens and to determine the phylogenetic relationship of Fusarium sp. 2 NFX06 with other endophytic and pathogenic isolates of different plant species.

\section{Materials and Method}

2.1. Study Area and Collection of Plant Material. N. foetida, commonly known as "Amrutha" is a medicinal plant that belongs to the family Icacinaceae and it was selected for the study because of its well known pharmacological properties. 


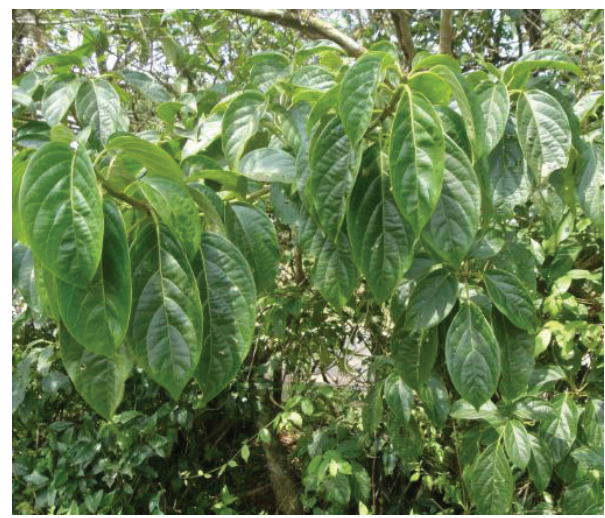

FIgURE 1: Nothapodytes foetida.

The plant samples were collected in the month of August from Agumbe forest located at $13^{\circ} 30^{\prime \prime} \mathrm{N}$ and $75^{\circ} 2^{\prime \prime} \mathrm{E}$ in the Western Ghats, Dakshina Karnataka, India (Figure 1). The plant material was identified and authenticated by an experienced botanist. Fresh and healthy parts of the plant like leaves, stem, seed, and fruits were cut with a sterile scalpel and stored at $4^{\circ} \mathrm{C}$ in a sterile polythene bag prior to use.

\subsection{Isolation and Identification of Endophytic Fungi. Isolation} was carried out as described by Wang et al. [19], with little modifications. Plant samples were surface sterilized with $75 \%$ ethanol (1 minute) and $2.5 \%$ sodium hypochlorite (3 minutes) followed by washing with sterile distilled water (2 minutes). Each plant sample was cut aseptically into $0.5 \mathrm{~cm}$ long segment and placed on petri dishes containing potato dextrose agar (PDA) supplemented with chloramphenicol $(50 \mu \mathrm{g} / \mathrm{mL}$, Sigma) and streptomycin sulphate $(250 \mu \mathrm{g} / \mathrm{mL}$ Sigma). The plates were sealed using Parafilm and incubated at $25^{\circ} \mathrm{C} \pm 1^{\circ} \mathrm{C}$ in a light chamber with 12 hours of light followed by 12 hours of dark cycles [20]. The petri dishes were monitored every day to check the growth of endophytic fungal colonies from the plant segments. As and when the hyphal tips emerged out from plant segments they were isolated and subcultured and brought to pure culture by serial subculturing. Identification of fungal endophytes was carried out based on their microscopic and macroscopic characteristics. Lactophenol cotton blue staining method was used for staining the fungal cultures [21] and visualized under microscope (MOTIC BA 400).

2.3. Determination of Species Diversity. Colonization rate (CR) was calculated as the total number of plant tissue segments infected by fungi divided by the total number of segments incubated [22]. Isolation rate (IR) was determined as the number of isolates obtained from plant segments divided by the total number of segments incubated. Colonization frequency (CF \%) was calculated as the number of plant segments colonized by a single endophyte divided by the total number of segments observed $\times 100$. Isolation frequency (IF \%) was calculated as the total number of isolates of one species divided by the total number of isolates in that sample $\times 100$. Simpson dominance index and ShannonWiener's diversity index were calculated for fungal diversity $[23,24]$.

Simpson's index of diversity was calculated using formula $1-D$ as given in the following equation:

$$
D=\frac{\sum n(n-1)}{N(N-1)}
$$

where $n$ is the total number of organisms of a particular species and $N$ is the total number of organisms of all species.

Shannon-Wiener diversity index was calculated using the following equation:

$$
H_{s}=-\sum_{i=1}^{S}\left(P_{i}\right)\left(\ln P_{i}\right)
$$

where $H_{s}$ is the symbol for the diversity in a sample of $S$ species or kinds, $S$ is the number of species in the sample, $P_{i}$ is the relative abundance of $i$ th species or kinds measures = $n / N, N$ is the total number of individuals of all kinds, $n_{i}$ is the number of individuals of $i$ th species, and $\ln$ is the $\log$ to base 2 .

\subsection{Fungal Cultivation and Determination of Antimicrobial Activity}

2.4.1. Test Microorganisms. The test microorganisms used in this study included three bacterial strains (S. aureus (ATCC 25923), E. coli (ATCC 25922), and P. aeruginosa (ATCC 27853)) and one yeast C. albicans (ATCC 69548). Inoculum of the test microorganisms was adjusted to a McFarland 0.5 standard in optical density corresponding to 1 to $2 \times$ $10^{8} \mathrm{cfu} / \mathrm{mL}$ and $3 \times 10^{8} \mathrm{cfu} / \mathrm{mL}$ for bacteria yeasts were used. The concentrations were confirmed via spectrophotometer readings at 580 and $626 \mathrm{~nm}$, respectively. Yeast samples were inoculated on Sabouraud agar (1\% peptone, 4\% dextrose, and $2 \%$ agar), and the bacteria were plated on Brain Heart Infusion agar (Difco) using a swab.

2.4.2. Fermentation. The fungal fermentation was carried out using $100 \mathrm{~mL}$ of potato dextrose broth (PDB) in $250 \mathrm{~mL}$ of Erlenmeyer flask inoculated with $(1 \mathrm{~cm} \times 1 \mathrm{~cm})$ mycelial agar plug taken from an actively growing colony on potato dextrose agar plate. It was then incubated at a temperature of $25^{\circ} \pm 1^{\circ} \mathrm{C}$ and at $120 \mathrm{rpm}$ under light and dark conditions of 12 hours. After 14 days of fermentation the biomass was separated from the broth by filtration using sterilized preweighed filter cloth.

2.4.3. Antimicrobial Screening of Fungal Endophytes. The antimicrobial activity of the fermentation broth was carried out for the 35 endophytic fungal isolates. The fermented broth was sterilized by filtration with $0.22 \mu \mathrm{m}$ Millipore syringe filters and $50 \mu \mathrm{L}$ of the broth were tested by modified agar well diffusion assay as described by NCCLS [25]. The antimicrobial activity was assessed by the diameter $(\mathrm{mm})$ of inhibition zones relative to those of positive and negative 
TABLE 1: Colonization and isolation rate of endophytic fungi from different plant tissues of $N$. foetida collected from Agumbe forest.

\begin{tabular}{|c|c|c|c|c|c|}
\hline & Leaf (NFX) & Stem (NFS) & Seeds (NFB) & Fruit (NFT) & Total \\
\hline No. of samples & 100 & 50 & 50 & 50 & 250 \\
\hline No. of samples yielding fungi & 88 & 18 & 12 & 36 & 154 \\
\hline No. of isolates & 110 & 24 & 23 & 46 & 170 \\
\hline Colonization rate (CR \%) & 88 & 36 & 24 & 72 & 61.6 \\
\hline Isolation rate (IR) & 1.1 & 0.48 & 0.46 & 0.92 & 0.68 \\
\hline
\end{tabular}

controls. Streptomycin and Fluconazole were coassayed as positive antimicrobial references with DMSO as negative control.

2.5. PCR Amplification, DNA Sequencing, and Phylogenetic Analysis of Representative Endophytic Fungi. Polymerase chain reaction was performed to amplify specifically the ITS region of the fungal genome. The fungal ITS regions, including the intervening $5.8 \mathrm{~S}$ gene and the flanking ITS1 and ITS2, were amplified with universal primers ITS 4 (5'TCCTCCGCTTATTGATATGC $\left.3^{\prime}\right)$ and ITS 5 ( $5^{\prime}$ GGAAGTAAAAGTAACAAGG3') designed by White et al. [26]. Amplification was performed in a $50 \mu \mathrm{L}$ reaction mixture containing $28 \mu \mathrm{L}$ MilliQ Water, $5 \mu \mathrm{L}$ of $10 \mathrm{X} \mathrm{Mg}$ free PCR buffer, $2 \mu \mathrm{L}$ of $25 \mathrm{mM} \mathrm{MgCl}_{2}, 5 \mu \mathrm{L}$ of $2.5 \mathrm{mM}$ deoxyribonucleotide triphosphates (dNTPs), $2 \mu \mathrm{L}$ each of $10 \mu \mathrm{M}$ primers (ITS4 and ITS5), $2 \mu \mathrm{L}$ of DNA template, $2 \mu \mathrm{L}$ of 2.5 units of Taq DNA polymerase, and $2 \mu \mathrm{L}$ of DMSO. The thermal cycle consisted of 3-minute initial denaturation at $94^{\circ} \mathrm{C}$, followed by 35 cycles of 30 -second denaturation at $94^{\circ} \mathrm{C}, 30$-second primer annealing at $54^{\circ} \mathrm{C}, 1$-minute extension at $72^{\circ} \mathrm{C}$, and a final 10 -minute extension at $72^{\circ} \mathrm{C}$. The PCR products were examined by electrophoresis in $1 \%$ $(\mathrm{w} / \mathrm{v})$ agarose gel with ethidium bromide $(10 \mathrm{mg} / \mathrm{mL})$ with a 100-base-pair ladder and checked for size and purity. The purified PCR product was sequenced using the forward and reverse primer in Applied Biosystems 3130 Genetic Analyser.

The consensus sequence obtained was subjected to BLAST search to assign putative identity, designation of operational taxonomic units based on sequence similarity measures, and phylogenetic inference. It was then aligned with other sequences of endophytic and pathogenic F. oxysporum downloaded from GenBank to determine their possible evolutionary relationship using MEGA program [27].

\section{Results and Discussion}

Endophytic fungi are known to be ubiquitous in nature and every plant species examined to date has been found colonized with fungal endophytes. It has been found that a single plant species may harbour hundreds of endophytes and may inhabit all available tissues, including leaves, petioles, stems, twigs, bark, xylem, roots, fruit, flowers, and seeds [2830].

3.1. Species Diversity. In the present study a total of 170 isolates of endophytic fungi were recovered from 250 samples of leaf, stem, seed, and fruit of ten N. foetida trees. The population of Zygomycetes and basidiomycetes were totally absent in this study and usually they are isolated in very low numbers in plant endophyte research as reported by Suryanarayanan et al. [31]. Colonization rates (CR \%) of leaf, stem, seed, and fruit were found to be $(88.0 \%, 36.0 \%$, $24.0 \%$, and $72.0 \%$ ) and isolation rates (IR) of leaf, stem, seed, and fruit were found to be (1.1, 0.48, 0.46, and 0.92), respectively (Table 1$)$. It indicates a wide variation between the segments of plants selected. Endophytic fungi were more prevalent on leaf tissue $(39.45 \%)$ than on stem $(16.32 \%)$, seed (14.96\%), and fruit tissues (29.25\%) which comprises $6.47 \%$ ascomycetes, $34.70 \%$ coelomycetes, $75.29 \%$ hyphomycetes, and $1.17 \%$ sterile fungi, respectively. Colonization frequency (Table 2) indicates that Colletotrichum sp. 1, Pestalotiopsis sp., Aspergillus flavus, Alternaria sp., Fusarium sp. 1, Fusarium sp. 2, Fusarium sp. 3, and Penicillium sp. 2 were the common isolates found in leaf, stem, seed, and fruit whereas Chaetomium sp., Drechslera sp., and Mycelia sterilia were restricted to the leaf tissues.

As shown in Table 3, this difference in prevalence may be tissue specific which may be due to their anatomical structure $[32,33]$. In the comparative study of twig and leafassociated endophytes in Quercus ilex [34], the commonest endophytes were found only in leaves, whereas the remainder were found in both leaves and twigs, but no twig-specific taxa were recovered. Similarly no bark specific taxa were found in Kigelia pinnata by Maheswari and Rajagopal [18]. This interestingly coincides with the present study, as there were no stem, seed, or fruit-specific taxa in the overall isolates.

3.2. Effect of Secondary Metabolites of Endophytic Fungi on Selected Pathogens. The endophytic fungi were evaluated for their antimicrobial activity against some clinically significant human pathogens. The fermentation broths of 35 endophytic fungi were screened for antimicrobial activity against three pathogenic bacterial strains, $S$. aureus, E. coli, and $P$. aeruginosa and one yeast C. albicans. $88.57 \%, 74.28 \%, 62.85 \%$, and $65.71 \%$ of isolates have shown activity against $S$. aureus, $P$. aeruginosa, E. coli, and C. albicans, respectively.

NFX 06-Fusarium sp. 2, NFX 23-Fusarium sp. 5, and NFB 04-Penicillium sp. 3 isolated from leaves and seeds, respectively, were found to exhibit very good activity against all the pathogenic strains with a zone of inhibition of more than $15 \mathrm{~mm}$. NFX 13-Penicillium sp. 1 and NFX 20-Phomopsis sp. 2 isolated from leaf, NFS 02-Xylaria sp. 4 isolated from stem, and NFB 02-Emericella isolated from seeds have shown a zone of inhibition of about 10 to $15 \mathrm{~mm}$ against the bacterial pathogens and more than $15 \mathrm{~mm}$ against C. albicans. 
TABLE 2: Endophytic fungi isolated from different parts of N. foetida.

\begin{tabular}{|c|c|c|c|c|c|c|c|c|}
\hline Endophytes & Leaf & CF (\%) & Stem & CF (\%) & Seed & CF (\%) & Fruit & CF (\%) \\
\hline \multicolumn{9}{|l|}{ Ascomycetes } \\
\hline Chaetomium sp. & 2 & 2 & - & - & - & - & - & - \\
\hline Xylaria sp. & 6 & 12 & 1 & 2 & - & - & 2 & 4 \\
\hline \multicolumn{9}{|l|}{ Coelomycetes } \\
\hline Colletotrichum sp. 1 & 14 & 14 & 1 & 2 & 1 & 2 & 2 & 4 \\
\hline Colletotrichum sp. 2 & 3 & 3 & - & - & - & - & 1 & 2 \\
\hline Pestalotiopsis sp. & 8 & 8 & 2 & 4 & 1 & 2 & 3 & 6 \\
\hline Phomopsis sp. 1 & 12 & 12 & - & - & 2 & 4 & 5 & 10 \\
\hline Phomopsis sp. 2 & 5 & 5 & 3 & 6 & - & - & - & - \\
\hline \multicolumn{9}{|l|}{ Hyphomycetes } \\
\hline Aspergillus flavus & 7 & 7 & 3 & 6 & 4 & 8 & 1 & 2 \\
\hline Aspergillus niger & 2 & 2 & - & - & 2 & 4 & 4 & 8 \\
\hline Aspergillus terreus & - & - & - & - & 1 & 2 & 1 & 2 \\
\hline Curvularia sp. & 6 & 6 & 1 & 2 & 1 & 2 & - & - \\
\hline Alternaria sp. & 6 & 6 & 2 & 4 & 1 & 2 & 2 & 4 \\
\hline Drechslera sp. & 1 & 1 & - & - & - & - & - & - \\
\hline Fusarium sp. 1 & 8 & 8 & 2 & 4 & 1 & 2 & 4 & 8 \\
\hline Fusarium sp. 2 & 6 & 6 & 1 & 2 & 2 & 4 & 6 & 12 \\
\hline Fusarium sp. 3 & 4 & 4 & 1 & 2 & 2 & 4 & 9 & 18 \\
\hline Trichoderma sp. & 4 & 4 & - & - & - & - & 2 & 4 \\
\hline Penicillium sp. 1 & 5 & 5 & 3 & 6 & - & - & 1 & 2 \\
\hline Penicillium sp. 2 & 9 & 9 & 4 & 8 & 4 & 8 & 3 & 6 \\
\hline \multicolumn{9}{|l|}{ Mycelia sterilia } \\
\hline Morphotype 1 & 1 & 1 & - & - & - & - & - & - \\
\hline Morphotype 2 & 1 & 1 & - & - & - & - & - & - \\
\hline
\end{tabular}

TABLE 3: Species diversity in terms of dominance, richness and evenness of endophytic fungal assemblages in different tissues of N. foetida.

\begin{tabular}{lccccc}
\hline Tissue & Total number of taxa & Total number of isolates & Simpson index (I-D) & Shannon-Wiener index (Hs) & Evenness index \\
\hline Leaf & 20 & 110 & 0.9302 & 2.794 & 0.8175 \\
Stem & 12 & 24 & 0.8958 & 2.362 & 0.8841 \\
Seed & 12 & 22 & 0.8884 & 2.335 & 0.8607 \\
Fruit & 15 & 46 & 0.8998 & 2.485 & 0.8002 \\
\hline
\end{tabular}
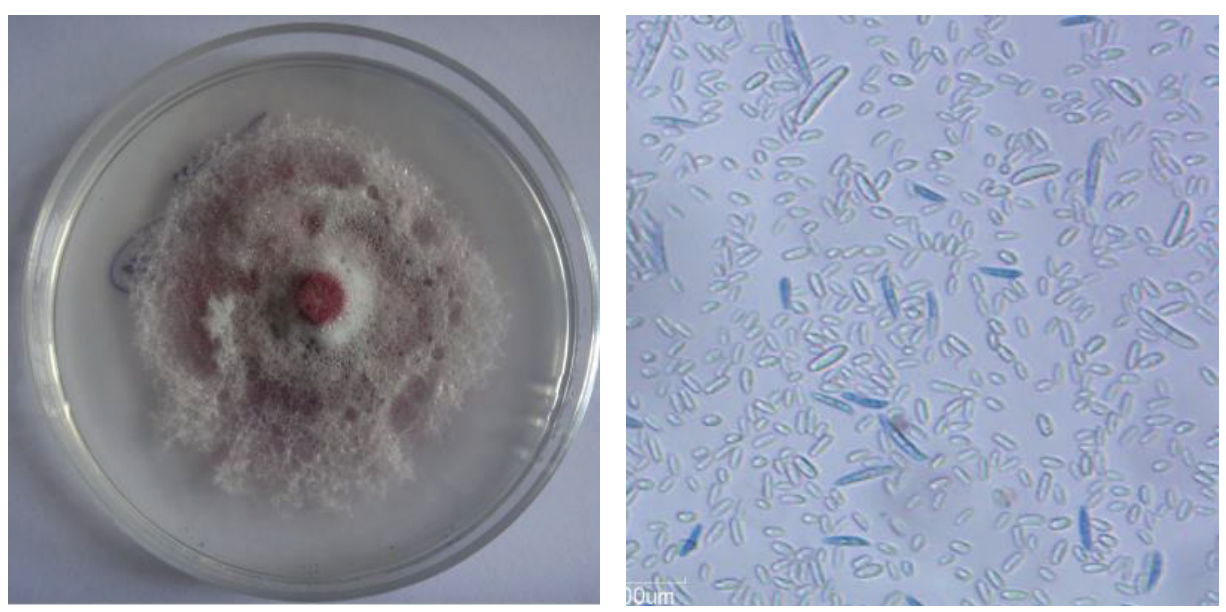

FIgURe 2: Colony morphology and conidia of endophytic fungus Fusarium oxysporum NFX06. 
TABLE 4: Antimicrobial activity of the fermentation broth of endophytic fungi isolated from different parts of $N$. foetida.

\begin{tabular}{|c|c|c|c|c|c|}
\hline \multirow{2}{*}{ Endophytic fungal taxa } & \multirow{2}{*}{ Strain no. } & \multicolumn{4}{|c|}{ Microorganism tested } \\
\hline & & S. aureus & P. aeruginosa & E. coli & C. albicans \\
\hline Alternaria sp. & NFX 01 & + & - & - & + \\
\hline Aspergillus niger & NFX 02 & + & + & - & - \\
\hline Aspergillus flavus & NFX 03 & + & - & - & - \\
\hline Xylaria sp. & NFX 04 & ++ & + & - & - \\
\hline Fusarium sp. 1 & NFX 05 & + & + & + & ++ \\
\hline Fusarium sp. 2 & NFX 06 & +++ & +++ & +++ & +++ \\
\hline Colletotrichum sp. 1 & NFX 07 & ++ & + & + & + \\
\hline Colletotrichum sp. 2 & NFX 08 & + & + & + & ++ \\
\hline Phomopsis sp. 1 & NFX 09 & +++ & ++ & ++ & ++ \\
\hline Pestalotiopsis sp. 1 & NFX 10 & + & + & + & + \\
\hline Pestalotiopsis sp. 1 & NFX 11 & ++ & + & - & - \\
\hline Fusarium sp. 2 & NFX 12 & ++ & + & + & ++ \\
\hline Penicillium sp. 1 & NFX 13 & ++ & ++ & ++ & +++ \\
\hline Penicillium sp. 2 & NFX 14 & ++ & + & + & + \\
\hline Xylaria sp. & NFX 15 & - & - & - & - \\
\hline Pestalotiopsis sp. 2 & NFX 16 & + & - & - & - \\
\hline Curvularia sp. & NFX 17 & - & - & - & - \\
\hline Drechslera sp. & NFX 18 & + & + & - & - \\
\hline Pestalotiopsis sp. 2 & NFX 19 & + & - & - & - \\
\hline Phomopsis sp. 2 & NFX 20 & ++ & ++ & ++ & +++ \\
\hline Phomopsis sp. 2 & NFX 21 & + & - & - & - \\
\hline Phomopsis sp. 1 & NFX 22 & ++ & + & + & + \\
\hline Fusarium sp. 1 & NFX 23 & +++ & +++ & +++ & +++ \\
\hline Xylaria sp. & NFS 01 & - & - & - & - \\
\hline Xylaria sp. & NFS 02 & ++ & ++ & ++ & +++ \\
\hline Phomopsis sp. 2 & NFS 03 & + & + & + & + \\
\hline Aspergillus terreus & NFB 01 & + & + & + & + \\
\hline Aspergillus niger & NFB 02 & ++ & ++ & ++ & +++ \\
\hline Colletotrichum sp. 2 & NFB 03 & + & + & + & ++ \\
\hline Penicillium sp. 2 & NFB 04 & +++ & +++ & +++ & +++ \\
\hline Pestalotiopsis sp. 2 & NFT 01 & ++ & ++ & ++ & ++ \\
\hline Fusarium sp. 2 & NFT 02 & ++ & ++ & + & ++ \\
\hline Colletotrichum sp. 1 & NFT 03 & ++ & + & ++ & +++ \\
\hline Colletotrichum sp. 2 & NFT 04 & + & + & + & + \\
\hline \multirow[t]{3}{*}{ Xylaria sp. } & NFT 05 & - & - & - & - \\
\hline & Streptomycin & +++ & +++ & +++ & - \\
\hline & Fluconozole & - & - & - & +++ \\
\hline
\end{tabular}

NFT 01-Pestalotiopsis sp. 3 isolated from fruit have shown zone of inhibition of about 10 to $15 \mathrm{~mm}$ against all the tested microorganisms. NFX 09-Phomopsis sp. 1 has shown a zone of inhibition more than $15 \mathrm{~mm}$ against $S$. aureus while showing 10 to $15 \mathrm{~mm}$ against all the other tested microorganisms.

NFX 01-Trichoderma sp. 1, NFX 02 -A. niger, NFX 03A. flavus, NFX 04-Xylaria sp. 1, NFX 05-Fusarium sp. 1, NFX 16-Pestalotiopsis sp. 2, NFX 18-Fusarium sp. 4, NFX 19Pestalotiopsis sp. 2, and NFX 21-Phomopsis sp. 3 were found to exhibit low activity of less than $10 \mathrm{~mm}$ zone of inhibition. According to Fabry et al. [35], the endophytic fungi that showed low antimicrobial activity might possess the active compound in a lesser concentration. And the concentration of these compounds could be enhanced by considering some factors like mode of fermentation, concentration of inoculum, period of incubation, solvents used for extraction, and most importantly purification process [36].

NFX 15-Xylaria sp. 2, NFX 17-Drechslera sp. 1, NFS 01Xylaria sp. 3, and NFT 05-Lasiodiplodia sp. 1 isolated from leaf, stem, and fruit, respectively, were found to exhibit no activity against the selected human pathogens. Among all the isolates, NFX 06-Fusarium sp. 2 (Figure 2) has shown maximum zone of inhibition, as shown in Table 4, of about $17.7 \mathrm{~mm}$ hence further studies were carried out with this isolate.

3.3. Phylogenetic Placement of F. oxysporum. Molecular methods to determine the genetic diversity within the species 
TABLE 5: List of F. oxysporum strains used in this study and their GenBank accession numbers.

\begin{tabular}{|c|c|c|c|c|}
\hline Species & No. of base pairs & Source/host & Country & Genbank accession no. \\
\hline \multicolumn{5}{|c|}{ Endophytic isolates } \\
\hline Fusarium oxysporum NFX06 & $510 \mathrm{bp}$ & Nothapodytes foetida & India & KC914432* \\
\hline F. oxysporum AC30 & $594 \mathrm{bp}$ & Acorus calamus & India & GU056168 \\
\hline F. oxysporum f. sp. gladioli UAS007 & $528 \mathrm{bp}$ & Nothapodytes nimmoniana & India & FJ158124.1 \\
\hline F. oxysporum JRE 1 & $497 \mathrm{bp}$ & Juniperus recurva & India & EF591767.1 \\
\hline F. oxysporum D 16 & $517 \mathrm{bp}$ & Annona squamosa & China & EF488410.1 \\
\hline F. oxysporum D 17 & $510 \mathrm{bp}$ & Annona squamosa & China & EF488411.1 \\
\hline F. oxysporum & 543 bp & Scuticaria irwiniana & Brazil & FJ605247.1 \\
\hline F. oxysporum UFMGCB 1376 & $543 \mathrm{bp}$ & Acianthera teres & Brazil & FJ605244.1 \\
\hline F. oxysporum $\mathrm{F} 35$ & $515 \mathrm{bp}$ & Taxus cuspidata & South Korea & AY555719.1 \\
\hline F. oxysporum DC-1-67 & $493 \mathrm{bp}$ & Dracaena cambodiana & China & FJ449900.1 \\
\hline F. oxysporum EYR11 & 549 bp & Pinus massoniana & China & EU888922 \\
\hline F. oxysporum FuO139 & $561 \mathrm{bp}$ & Schlumbergera truncata & Italy & KC196121 \\
\hline F. oxysporum CMT6 & $527 \mathrm{bp}$ & Phaseolus vulgaris & Brazil & JQ754006 \\
\hline F. oxysporum & 545 bp & Paris polyphylla var. chinensis & China & JF776163 \\
\hline F. oxysporum DB0612101 & $515 \mathrm{bp}$ & - & - & HQ682196 \\
\hline F. oxysporum SFCF20120912-05 & 548 bp & Pinus thunbergii & Korea & KF313101.1 \\
\hline F. oxysporum REF 213 & $555 \mathrm{bp}$ & Ephedra distachya & Hungary & JN859433 \\
\hline F. oxysporum DH-42 & $581 \mathrm{bp}$ & Rehmannia glutinosa & China & HM346538.1 \\
\hline F. oxysporum JJ002 & $541 \mathrm{bp}$ & Ginkgo biloba & China & DQ166550 \\
\hline F. oxysporum FOFB62 & $564 \mathrm{bp}$ & Grevillea robusta & Kenya & HQ651161 \\
\hline F. oxysporum Aug021 & $543 \mathrm{bp}$ & Pecteilis susannae (L.) Rafin & Thailand & GQ862347 \\
\hline \multicolumn{5}{|c|}{ Pathogenic Isolates } \\
\hline F. oxysporum $18 \mathrm{P}$ & $487 \mathrm{bp}$ & Bean & Mexico & FJ619940 \\
\hline F. oxysporum f. cubense $115 \mathrm{HT}$ & $569 \mathrm{bp}$ & Banana & India & DQ889176.1 \\
\hline F. oxysporum GXF-6 & 544 bp & Hybrid bamboo & China & EU285554.1 \\
\hline F. oxysporum 544 & $544 \mathrm{bp}$ & Bupleurum chinensis & China & EU862240 \\
\hline F. oxysporum $6 e-35$ & $515 \mathrm{bp}$ & Capsicum annum & Mexico & AY728210 \\
\hline F. oxysporum nazar 1 & $545 \mathrm{bp}$ & Agave tequilana & Mexico & EU161243 \\
\hline F. oxysporum f. sp. niveum $1 \mathrm{ZF} 1$ & $545 \mathrm{bp}$ & Watermelon & China & EU588397 \\
\hline F. oxysporum f. sp. lilli FF-2 & $543 \mathrm{bp}$ & Lily & Taiwan & AY684919 \\
\hline F. oxysporum f.sp. vasinfectum F1TP0001 & $542 \mathrm{bp}$ & Tulip & Mexico & DQ979010 \\
\hline F. oxysporum f. sp. vasinfectum & 545 bp & Cotton & China & EU849584 \\
\hline F. oxysporum $\mathrm{R} 1$ & 543 bp & Atractylodes & China & JX885462 \\
\hline F. oxysporum 857 & $564 \mathrm{bp}$ & Macrocephala & China & JN232190 \\
\hline F. oxysporum GLB3 & 567 bp & - & China & GU136492 \\
\hline F. oxysporum 08YSJG & 567 bp & - & China & GU136493 \\
\hline F. oxysporum & $527 \mathrm{bp}$ & Pinus sylvestris & Sweden & HM036595 \\
\hline F. oxysporum & $564 \mathrm{bp}$ & Grevillea robusta & - & HQ651161 \\
\hline F. oxysporum & $552 \mathrm{bp}$ & - & UK & AY147369 \\
\hline F. oxysporum XSD-73 & $570 \mathrm{bp}$ & Dioscorea collettii var. hypoglauca & China & EU326215 \\
\hline F. oxysporum XSD-78 & $571 \mathrm{bp}$ & Polygonatum sibirilum red & China & EU326216 \\
\hline F. oxysporum OT0330 & $546 \mathrm{bp}$ & Roots of willows & - & GU934524 \\
\hline
\end{tabular}

*Endophytic fungus used in the present study.

of F. oxysporum [37] and genetic diversity within pathogenic and nonpathogenic isolates with endophytic isolates from various plants $[38,39]$ and also with other isolates that exist as pathogens, saprophytes, and endophytes [40] have been reported. In this study, an attempt was made to place an endophytic F. oxysporum isolated from $N$. foetida leaves with other endophytic and pathogenic F. oxysporum of different plant species (Table 5). Phylogenetic tree was generated using maximum parsimony method. The generated tree showed twelve clades and one independent lineage which have descended from a pathogenic $F$. oxysporum ancestor (Figure 3).

The evolutionary relationship of 40 taxa revealed consistency index (0.229865), retention index (0.534473), and composite index (0.122857), respectively, with a tree length of 6295. Clade I showed two clusters with an endophytic F. oxysporum and in Clade II all the isolates were pathogenic F. oxysporum whereas both the clades shared common 


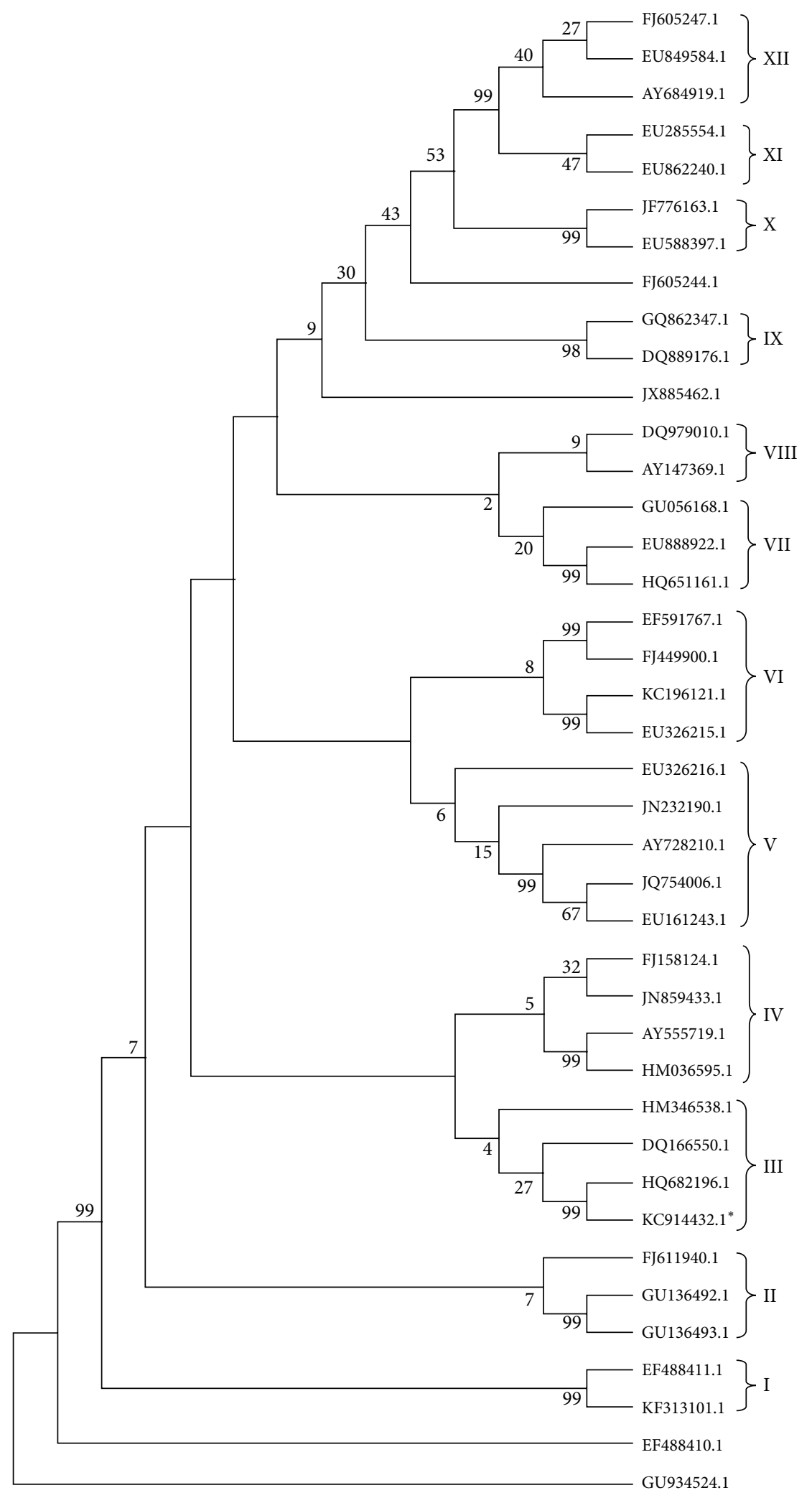

Figure 3: Tree showing phylogenetic relationship of 40 F. oxysporum strains. The evolutionary history was inferred using the maximum parsimony method. Tree number 1 out of the 280 most parsimonious trees (length $=6295$ ) is shown. The percentage of replicate trees in which the associated taxa clustered together in the bootstrap test (500 replicates) is shown next to the branches. ${ }^{*}$ denotes the endophytic fungus used in the present study. 
endophytic ancestor. Clade III has all endophytic descendants with a common endophytic ancestor. Clades IV and VI have two coevolved endophytic isolates with two major clusters giving rise to one pathogenic descendant. Clades VIII and XI have two clusters with all pathogenic isolates. Clades VII and XII have two endophytic isolates and one pathogenic isolate which depicts the possible evolution of a pathogenic strain from an endophytic isolate. Clades IX and X have two clusters each with an endophytic and pathogenic isolate coexisting together which shares a common pathogenic ancestor.

Based on the phylogenetic analysis we hypothesize that endophytic strains have given rise to pathogenic forms. This hypothesis is supported by the fact that there is a great deal of genetic relatedness between pathogenic and nonpathogenic F. oxysporum isolates, which has led some researchers to conclude that some particular pathogenic isolates might have evolved from nonpathogenic strains by mutations involving a few loci $[41,42]$.

\section{Conclusions}

However, this is perhaps the first report on endophytic fungal diversity of the endangered medicinal plant $N$. foetida of Agumbe forest. This study contributes to the understanding of species richness of endophytic fungi in different tissues of the plant like leaf, stem, seed, and fruit. More number of endophytic isolates in leaf tissue may be due to the fact that the sampling was done in a wet season and in many instances leaves sampled during the wet season harboured more endophytes than those screened during the dry season $[43,44]$. The rich diversity of Fusarium species as endophytes in different tissues of both the plants may be due to germination of more number of spores of this fungus due to favourable environmental condition. Most of the species isolated comprise mostly Fusarium, Penicillium, Colletotrichum, Pestalotiopsis, Aspergillus, and Alternaria which was in agreement with the results of Jeewon et al. [45] from Antidesma madagascariense. The result of antimicrobial activity indicated that most of the isolates showed varying degree of activity against the selected human test pathogens. Hence the endophytic fungi existing in the plant are potential sources of antimicrobial substances as reported by several researchers [46-49]. Among the 35 selected endophytes Fusarium sp. 2 has shown very good activity which was further identified based on ITS sequencing to be F. oxysporum strain NFX06 and submitted in the GenBank with the accession number KC914432. Phylogenetic analysis of the endophytic strain F. oxysporum NFX06 with the other endophytic and pathogenic F. oxysporum indicated that there is a strong relationship between the pathogenic and nonpathogenic F. oxysporum and from the results it was concluded that F. oxysporum NFX06 has evolved from an endophytic ancestor.

\section{Acknowledgments}

The authors are thankful to Manipal Life Science Centre for providing the facilities for identification of endophytic fungus. And they are grateful to retired Professor G. K. Bhat,
Poornaprajna College Mangalore, for helping them in finding and authenticating the plant.

\section{References}

[1] C. W. Bacon and J. White, Microbial Endophytes, Marcel Dekker, New York, NY, USA, 2000.

[2] M. M. Dreyfuss and I. H. Chapela, "Potential of fungi in the discovery of novel, low molecular weight pharmaceuticals," in The Discovery of Natural Products With Therapeutic Potential, V. P. Gullo, Ed., pp. 49-80, Butterworth-Heinemann, Boston, Mass, USA, 1994.

[3] A. E. Arnold, Z. Maynard, and G. S. Gilbert, "Fungal endophytes in dicotyledonous neotropical trees: patterns of abundance and diversity," Mycological Research, vol. 105, no. 12, pp. 1502-1507, 2001.

[4] I. R. Sanders, "Plant and arbuscular mycorrhizal fungal diversity-are we looking at the relevant levels of diversity and are we using the right techniques?" New Phytologist, vol. 164, no. 3, pp. 415-418, 2004.

[5] J. M. U'Ren, J. W. Dalling, R. E. Gallery et al., "Diversity and evolutionary origins of fungi associated with seeds of a neotropical pioneer tree: a case study for analysing fungal environmental samples," Mycological Research, vol. 113, no. 4, pp. 432-449, 2009.

[6] O. Petrini, T. N. Sieber, L. Toti, and O. Viret, "Ecology, metabolite production, and substrate utilization in endophytic fungi," Natural toxins, vol. 1, no. 3, pp. 185-196, 1992.

[7] G. Soca-Chafre, F. N. Rivera-Orduña, M. E. Hidalgo-Lara, C. Hernandez-Rodriguez, R. Marsch, and L. B. Flores-Cotera, "Molecular phylogeny and paclitaxel screening of fungal endophytes from Taxus globosa," Fungal Biology, vol. 115, no. 2, pp. 143-156, 2011.

[8] U. Pinruan, N. Rungjindamai, R. Choeyklin, S. Lumyong, K. D. Hyde, and E. B. G. Jones, "Occurrence and diversity of basidiomycetous endophytes from the oil palm, Elaeis guineensis in Thailand," Fungal Diversity, vol. 41, pp. 71-88, 2010.

[9] A. B. M. Vaz, R. C. Mota, M. R. Q. Bomfim et al., "Antimicrobial activity of endophytic fungi associated with Orchidaceae in Brazil," Canadian Journal of Microbiology, vol. 55, no. 12, pp. 1381-1391, 2009.

[10] L. H. Rosa, M. D. L. Almeida Vieira, I. F. Santiago, and C. A. Rosa, "Endophytic fungi community associated with the dicotyledonous plant Colobanthus quitensis (Kunth) Bartl. (Caryophyllaceae) in Antarctica," FEMS Microbiology Ecology, vol. 73, no. 1, pp. 178-189, 2010.

[11] G. Strobel, B. Daisy, U. Castillo, and J. Harper, "Natural Products from Endophytic Microorganisms," Journal of Natural Products, vol. 67, no. 2, pp. 257-268, 2004.

[12] H. W. Zhang, Y. C. Song, and R. X. Tan, "Biology and chemistry of endophytes," Natural Product Reports, vol. 23, no. 5, pp. 753771, 2006.

[13] J.-H. Song, "What's new on the antimicrobial horizon?" International Journal of Antimicrobial Agents, vol. 32, no. 4, pp. S207S213, 2008.

[14] A. L. Demain and S. Sanchez, "Microbial drug discovery: 80 Years of progress," Journal of Antibiotics, vol. 62, no. 1, pp. 5-16, 2009.

[15] H. Yu, L. Zhang, L. Li et al., "Recent developments and future prospects of antimicrobial metabolites produced by endophytes," Microbiological Research, vol. 165, no. 6, pp. 437449, 2010. 
[16] X. Liu, M. Dong, X. Chen, M. Jiang, X. Lv, and J. Zhou, "Antimicrobial activity of an endophytic Xylaria sp.YX-28 and identification of its antimicrobial compound 7-amino-4-methylcoumarin," Applied Microbiology and Biotechnology, vol. 78, no. 2, pp. 241-247, 2008.

[17] C. P. Narayan, W. K. Kim, S. K. Woo, M. S. Park, and S. H. $\mathrm{Yu}$, "Fungal endophytes in roots of aralia species and their antifungal activity," Journal of Plant Pathology, vol. 23, no. 4, pp. 287-294, 2007.

[18] S. Maheswari and K. Rajagopal, "Biodiversity of endophytic fungi in Kigelia pinnata during two different Seasons," Current Science, vol. 104, pp. 515-518, 2013.

[19] F. W. Wang, R. H. Jiao, A. B. Cheng, S. H. Tan, and Y. C. Song, "Antimicrobial potentials of endophytic fungi residing in Quercus variabilis and brefeldin a obtained from Cladosporium sp," World Journal of Microbiology and Biotechnology, vol. 23, no. 1, pp. 79-83, 2007.

[20] V. Gangadevi and J. Muthumary, "Taxol, an anticancer drug produced by an endophytic fungus Bartalinia robillardoides Tassi, isolated from a medicinal plant, Aegle marmelos Correa ex Roxb," World Journal of Microbiology and Biotechnology, vol. 24, no. 5, pp. 717-724, 2008.

[21] S. C. Parija, M. R. Shivaprakash, and S. R. Jayakeerthi, "Evaluation of lacto-phenol cotton blue (LPCB) for detection of Cryptosporidium, Cyclospora and Isospora in the wet mount preparation of stool," Acta Tropica, vol. 85, no. 3, pp. 349-354, 2003.

[22] O. Petrini, "Fungal endophytes of tree leaves," in Microbial Ecology of Leaves, pp. 179-197, Springer, New York, NY, USA, 1991.

[23] R. W. Poole, An Introduction to Quantitative Ecology, McGrawHill, New York, NY, USA, 1974.

[24] J. V. Groth and A. P. Roelfs, "The concept of measurement of phenotypic diversity in Puccinia graminis on wheat," Phytopathology, vol. 77, pp. 1394-1399, 1987.

[25] NCCLS, "Methods for determining bactericidal activity of antimicrobial agents," Approved Guideline M26-A, National Committee for Clinical Laboratory Standards, Wayne, Pa, USA, 1996.

[26] T. J. White, T. Bruns, S. Lee, and J. Taylor, "Amplification and direct sequencing of fungal ribosomal RNA genes for phylogenetics," in PCR Protocols: A Guide to Methods and Applications, M. A. Innis, D. H. Gelfand, J. J. Sninsky, and T. J. White, Eds., pp. 315-322, Academic Press, New York, NY, USA, 1990.

[27] K. Tamura, D. Peterson, N. Peterson, G. Stecher, M. Nei, and S. Kumar, "MEGA5: molecular evolutionary genetics analysis using maximum likelihood, evolutionary distance, and maximum parsimony methods," Molecular Biology and Evolution, vol. 28 , no. 10, pp. 2731-2739, 2011.

[28] K. Saikkonen, S. H. Faeth, M. Helander, and T. J. Sullivan, "Fungal endophytes: a continuum of interactions with host plants," Annual Review of Ecology and Systematics, vol. 29, pp. 319-343, 1998.

[29] I. H. Chapela and L. Boddy, "Fungal colonization of attached beech branches. I. Early stages of development of fungal communities," New Phytologist, vol. 110, no. 1, pp. 39-45, 1988.

[30] P. J. Fisher, O. Petrini, and B. C. Sutton, "A comparative study of fungal endophytes in leaves, xylem and bark of Eucalyptus in Australia and England," Sydowia, vol. 45, pp. 338-345, 1993.
[31] T. S. Suryanarayanan, V. Kumaresan, and J. A. Johnson, "Foliar fungal endophytes from two species of the mangrove Rhizophora," Canadian Journal of Microbiology, vol. 44, no. 10, pp. 1003-1006, 1998.

[32] K. Rajagopal and T. S. Suryanarayanan, "Isolation of endophytic fungi from leaves of neem (Azadirachta indica A. Juss.)," Current Science, vol. 78, no. 11, pp. 1375-1378, 2000.

[33] S.-Y. Lee, I. Nakajima, F. Ihara, H. Kinoshita, and T. Nihira, "Cultivation of entomopathogenic fungi for the search of antibacterial compounds," Mycopathologia, vol. 160, no. 4, pp. 321-325, 2005.

[34] P. J. Fisher, O. Petrini, L. E. Petrini, and B. C. Sutton, "Fungal endophytes from the leaves and twigs of Quercus ilex L. from England, Majorca and Switzerland," New Phytologist, vol. 127, no. 1, pp. 133-137, 1994.

[35] W. Fabry, P. O. Okemo, and R. Ansorg, "Antibacterial activity of East African medicinal plants," Journal of Ethnopharmacology, vol. 60, no. 1, pp. 79-84, 1998.

[36] P. Powthong, B. Jantrapanukorn, A. Thongmee, and P. Suntornthiticharoen, "Evaluation of endophytic fungi extracts for their antimicrobial activity from Sesbania grandiflora (L.) pers," International Journal of Pharmaceutical Biomedical Research, vol. 3, pp. 132-136, 2012.

[37] V. Edel, C. Steinberg, I. Avelange, G. Laguerre, and C. Alabouvette, "Comparison of three molecular methods for the characterization of Fusarium oxysporum strains," Phytopathology, vol. 85 , no. 5, pp. 579-585, 1995.

[38] K. S. Elais, R. W. Schneider, and M. M. Lear, "Analysis of vegetative compatibility group in nonpathogenic population of Fusarium oxysporum isolated from symptomless tomato root," Canadian Journal of Botany, vol. 69, pp. 2089-2094, 1991.

[39] S. L. Woo, A. Zoina, G. Del Sorbo et al., "Characterization of Fusarium oxysporum f. sp. phaseoli by pathogenic races, VCGs, RFLPs, and RAPD," Phytopathology, vol. 86, no. 9, pp. 966-973, 1996.

[40] B. P. Barik, K. Tayung, P. J. Narayan, and S. K. Dutta, "Phylogenetic placement of an endophytic fungus Fusarium oxysporum isolated from Acorus calamus rhizomes with antimicrobial activity," EJBS, vol. 2, no. 1, 2010.

[41] R. P. Baayen, K. O’Donnell, P. J. M. Bonants et al., “Gene genealogies and AFLP analyses in the Fusarium oxysporum complex identify monophyletic and nonmonophyletic formae speciales causing wilt and rot disease," Phytopathology, vol. 90, no. 8, pp. 891-900, 2000.

[42] K. Skovgaard, L. Bødker, and S. Rosendahl, "Population structure and pathogenicity of members of the Fusarium oxysporum complex isolated from soil and root necrosis of pea (Pisum sativum L.)," FEMS Microbiology Ecology, vol. 42, no. 3, pp. 367374, 2002.

[43] K. F. Rodrigues, "The foliar fungal endophytes of the Amazonian palm Euterpe oleracea," Mycologia, vol. 86, no. 3, pp. 376385, 1994.

[44] D. Wilson and G. C. CarrolL, "Infection studies of Discula quercina, an endophyte of Quercus garryana," Mycologia, vol. 86, no. 5, pp. 635-647, 1994.

[45] R. Jeewon, J. Ittoo, D. Mahadeb, Y. J. Fakim, H.-K. Wang, and A.-R. Liu, "DNA based identification and phylogenetic characterisation of endophytic and saprobic Fungi from Antidesma madagascariense, a medicinal plant in mauritius," Journal of Mycology, vol. 2013, Article ID 781914, 10 pages, 2013. 
[46] K. Tayung and D. K. Jha, "Antimicrobial evaluation ofsomefungal endophytes isolated frombarkofHimalayanyew," World Journal of AgriculturalSciences, vol. 2, pp. 489-494, 2006.

[47] J. Mohanta, K. Tayung, and U. B. Mohapatra, "Antimicrobial potentials of endophytic fungi inhabiting three ethnomedicinal plants of similipal biosphere reserve, India," Internet Journal of Microbiology, vol. 5, no. 2, 2008.

[48] S. Padhi and K. Tayung, "Antimicrobial activity and molecular characterization of an endophytic fungus, Quambalaria $s p$. isolated from Ipomoea carnea," Annals of Microbiology, vol. 63, no. 2, pp. 793-800, 2013.

[49] S. K. Jena and K. Tayung, "Endophytic fungal communities associated with two ethno-medicinal plants of similipal biosphere reserve, India and their antimicrobial prospective," Journal of Applied Pharmaceutical Science, vol. 3, p. S7, 2013. 

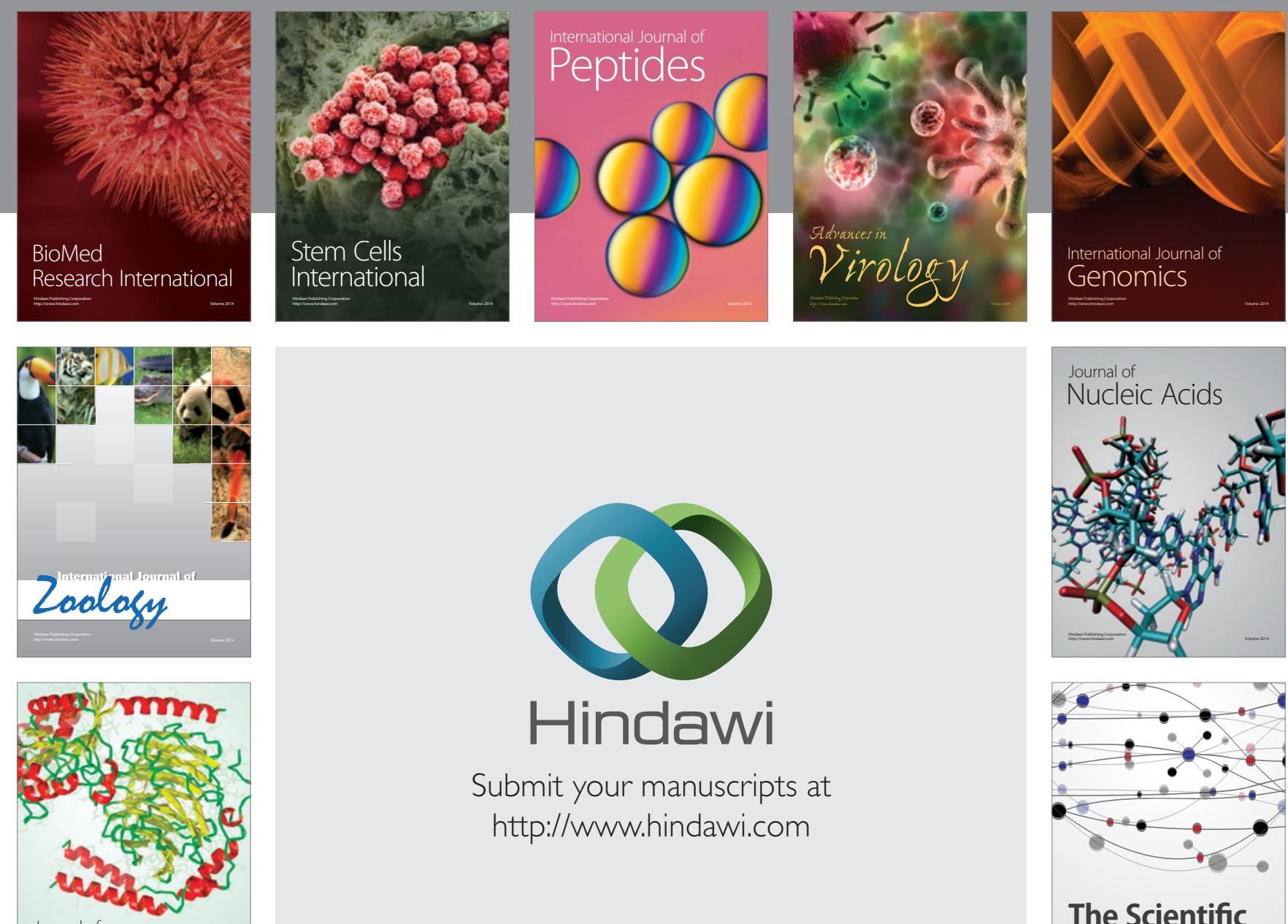

Submit your manuscripts at

http://www.hindawi.com

Journal of
Signal Transduction
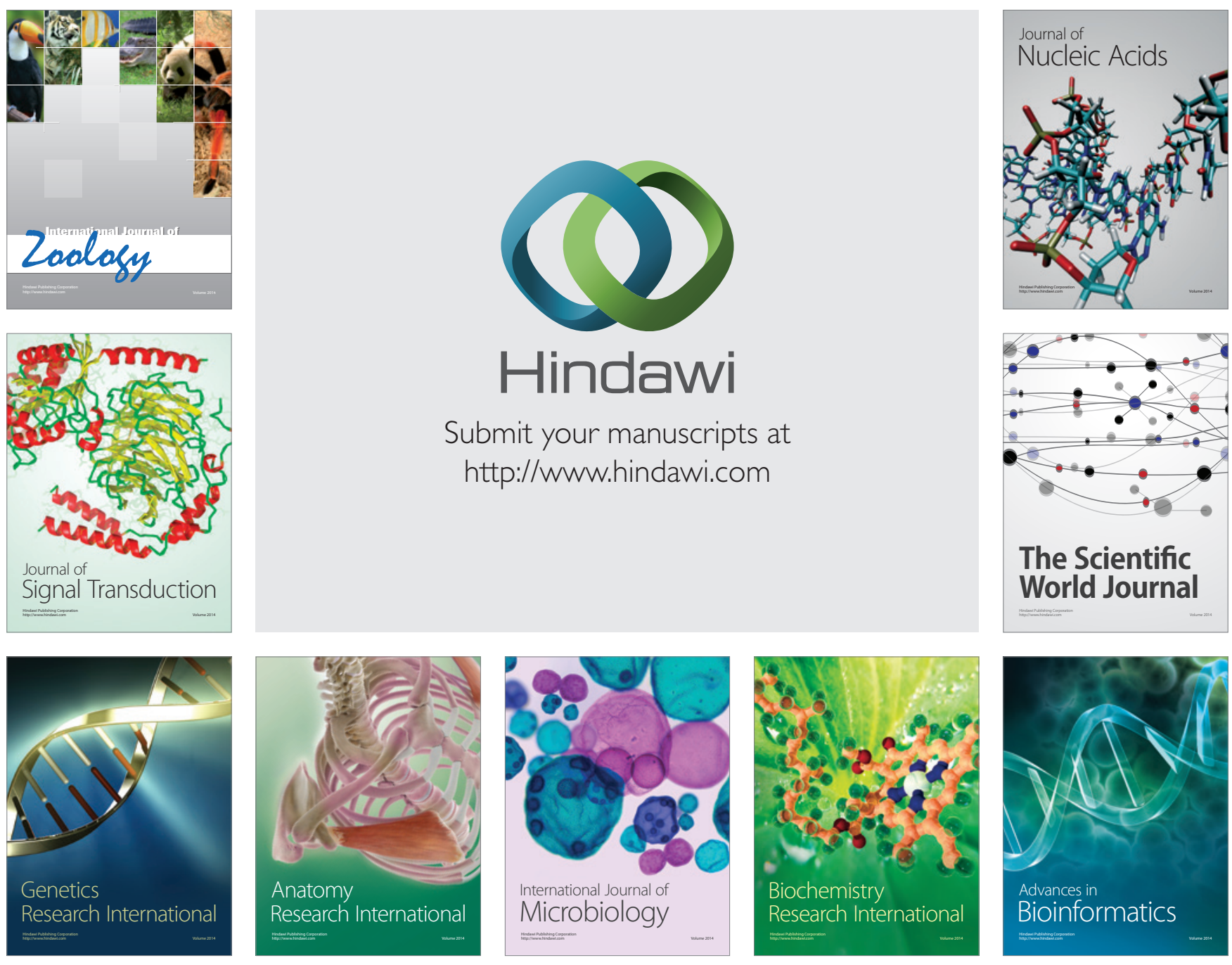

The Scientific World Journal
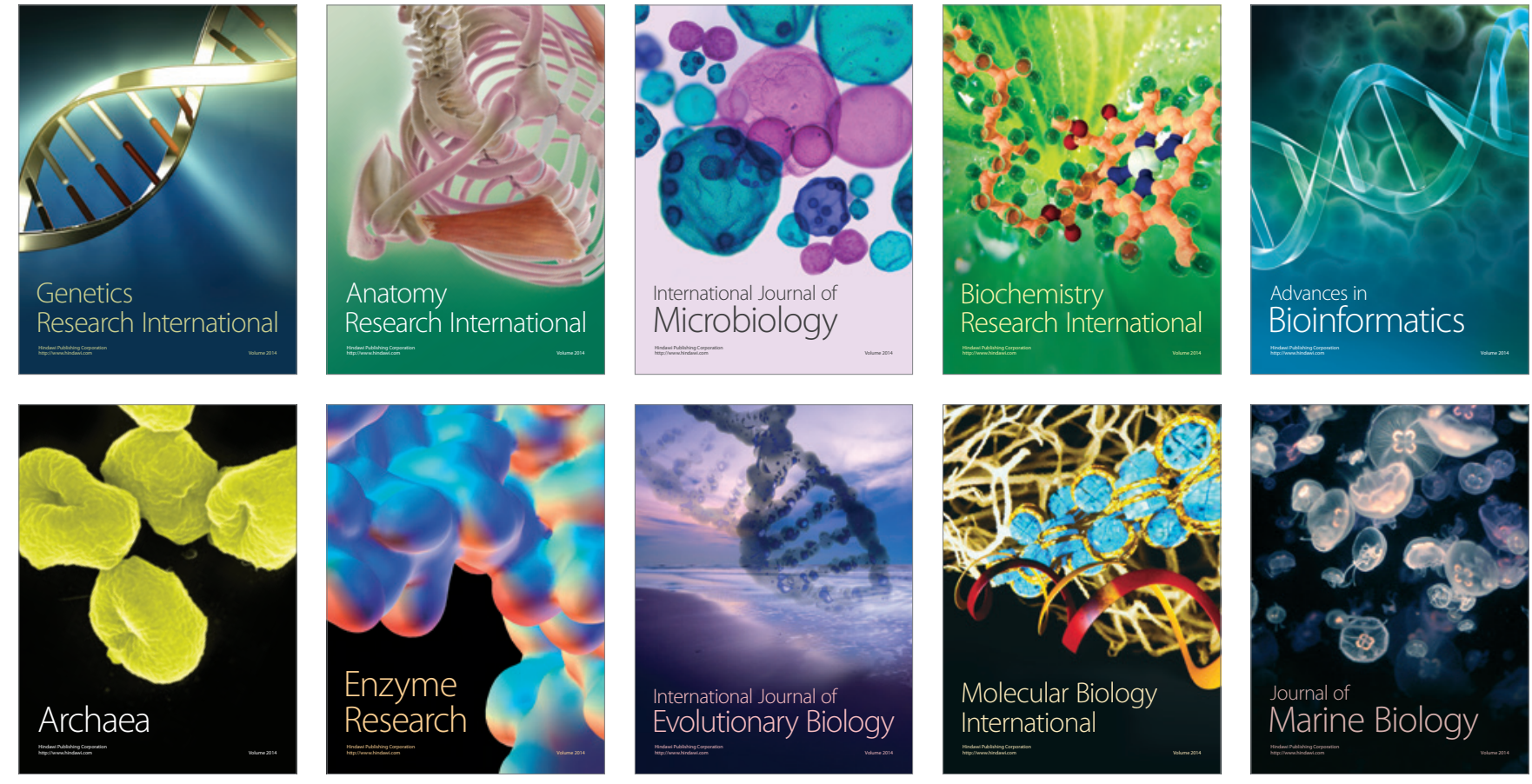